mouth of the flask, and make a few perforations with a pin, for the escape of a little alcoholic vapor. If the vessel be placed in a warm situation, thick and viscid drops of the copal, combined with alcohol, will slowiy fall into the liquid below, and gradually dissolve, until the whole of the copal is extracted. When dissolved, the clear liquor may be decanted from a very small quantity of sediment, and it will prove a mare transparent and beautiful varnish, than can be procured by any other method. The same process is applicable to other difficultly soluble resins, and will be found useful where rapidity is not required.

B.

\title{
Soda-Manufacture in Hungary.
}

Native carbonate of soda is found in greatest abundance in Little Cumania, particularly near Shegedin; it likewise occurs in many other places, in greater or smaller quantity. It effloresces, nut of the moist earth, forming a white crust, and in the spring of the year, before sunrise, it appears like an extensive covering of snow. With greater care than they now employ, the workmen might readily gather it sufficiently pure for ordinary technical purposes by raking. The whole of the surface is gathered, and sold to the soda manufacturers, who distinguish its quality and richness, by the taste. It is leached in square vats, until the remainder ceases to have a saline taste. The fluid is dark brown, and beside carbonate of soda, contains much sulphate and muriate of soda, humic acid, and other mechanical impurities. It is boiled down in a large sheet.iron pan, to a siropy consistence, transferred to an adjoining pan, and evaporated to dryness under constant stirring. The mass is of a dirty yellow, or brown, with white and black spots. It is gradually heated in a calcining furnace with the access of air, until vapors cease passing off; then fused at a higher temperature and taken out, when partially cooled. A large portion is employ ed in the country itself, in the manufacture of snap, the remainder sold as raw calcined soda, as there is no manufactory for crystalizing it. If the demand for it were increased, the proluction of this salt might be increased to three or four times the present anount, as the country contains numerous soda lakes. Beside Trieste, from which some of the productions of Hungary, find their way to the American market, there is a port on the Adriatic, belonging exclusively to that kingdom, whence we might obtain, at lower rates, the products of one of the most fertile countries of Europe. Selected from Frdmann's Journal, fur praktiche Chemie, Bd. xiii.

B.

On Galls used in the manufacture of Black Ink.

Blue aleppo galls are employed in great quantity, in the manufacture of black ink, in consequence of the large amount of tannin they contain, neariy all of which, by a judicious management, is converted into gallic acid. Being greatly superior to oak bark in their content of tannin, they might be substituted for it, in the process of tanning leather, were not their high price a serious impediment. They are excrescences on the leaf-stem of the quercus infectoria, growing in the Levant, and are produced by the incision of the female gall-wasp. There is, however, another kind of galls, the acom of the Quercus cerris, which receives a malformation from the in. cision of an insect, and produces a substance not unlike the aleppo galls, but much more irregular and with bold projecting points. They are lound abundantly in Hungary, and the Southern provinces of Austria, where they are employed in dyeing and tanning, particularly in the latter art. They 
are known under the name of Knoppern, in Germany, and Gallesa l'epine, in France, and in the former country, are considered but little inferior to good aleppo-galls. A matufactory has been established at Vienna, for obtain ing a solid extract from them, which has been successfully employed, in dyeing dark colors, and in tanning. Either the knoppern, or their extract, might be obtained at 'Trieste, and might prove a useful substitute for ordinary galls, whether in dyeing, or in the manufacture of ink. J. C. B.

FOK THE JOUKNAL OF THE FKANKLIN INSTITUTE,

\section{Assay of Gold.}

In the last number of the Journal, a new methol of assaying gold, proposed by Lewis Thompson, Esq., is extracted from the London and Edinburg Philusophical Magazine. It consists in adding to the gold assay-piece, an excess of silver, anl then fusing the mass down with the chlorides of silver and of sodium, to remove the base inetals. The silver is afterwards separated by nitric acid. "By this plan," says the author, "the tedious process of cupellation is aviiled."

It may not be unimportant, to some of the readers of the Journal, to be informed, that Mr. Thompson's plan differs from the usual one by cupellation, only in two particulars, in both of which the old process has manifestIy the advantage. In this process, lead alone is employed to remove the base metals, instead of the two chlorides, and it is simpler, perfectly effectual, and not subject to decrepitation. The second point of difference, is that a cupel, composed of bone ashes, is used instead of a crucible; and this cupel possesses the invaluable property of absorbing the oxides of lead, and of the baser metals, and leaving a clean button, composed only of gold and silver. In the vew process, this advantage is not presented, and there will be grains to be separated from the crucible, as after the operation of fluxing; - thus arlding not only to the labor of the process, but to the uncertainty of the result. We are, therefore, led to the conclusion, that the process proposell by Mr. Thompson, is more complicaled, more inaccurate, and even more "tedious," than that now in universal use. U. S. M.

\section{Postscript.}

Some time after the above article was communicated, an opportunity was taken of making trial of Mr. 'Thompson's method of assay, and the results render it proper to modify, in some degree, the above remarks. The gold, the fine silver, and the chloride of silver, were melted together in a small crucible, and the button of gold and silver formed was found to be much more perfect and better insulated than had been expected. Five assays were made, and the results, by the old and the new process, expressed in thousandths, were as follows:

$\begin{array}{rlccc}\text { No. 1, by cupellation, } & 968 & \text { by Thompson's process, } & 968.5 \\ 2, & \text { "“ } & 890 & 4 & 889^{*} \\ 3, & \text { " } & 936.5 & 4 & 936.7 \\ 4, & \text { " } & 900 & 4 & 900.2 \\ 5, & 460 & 4 & 460.5\end{array}$

This comparison of the two methods is certainly very satisfactory, the greatest difference being but one thousandth.

In employing Mr. Thompson's process, an cvil was observed which had not been anticipated. It is, that a sensible portion of the chloride of silver is rolatilized during the fusion, and consequently lost. To show this, the fol- 